\title{
OPTIMALISASI PENDAPATAN ASLI DAERAH PROVINSI NUSA TENGGARA TIMUR
}

\section{OPTIMIZATION OF ORIGINAL REVENUE INCOME EAST NUSA TENGGARA PROVINCE}

\author{
Suci Istiqlaala \\ aBadan Perencanaan Pembangunan Penelitian dan Pengembangan Daerah \\ Provinsi Nusa Tenggara Timur \\ E-mail: suciistiqlaal@gmail.com \\ Naskah Diterima : 20 Agustus 2019; Di-review : 25 Agustus 2019; Dimuat: 30 Agustus 2019
}

Copyright OFLOBAMORA 2019

\begin{abstract}
This study aims to identify the magnitude of sources of local revenue, the steps taken in increasing local revenue (PAD), explore the obstacles that occur in optimizing the sources of $P A D$, and strategic solutions in optimizing PAD. The research method is quantitative and qualitative (mix method). The results showed that the magnitude of the four sources of original regional income experienced a fluctuating revenue trend during 2013-2017. The contribution of the four sources of original regional income to regional income is considered low. The inhibiting factors for optimizing the original income of NTT Province consist of internal and external factors. Internal factors include institutional culture, administration (operational costs), information technology, geographical conditions, quality and quantity of human resources. Meanwhile, external factors include certain political interests, economic conditions of the community and public awareness. The strategies that have been implemented in optimizing NTT Province's original income include; strategy of intensification, extensification and improvement of service quality. Through AHP results, the alternative strategy chosen is to optimize the innovation strategy.
\end{abstract}

Keywords : Optimization; East Nusa Tenggara; East Nusa Tenggara Government; Regional Original Revenue; Financial.

\section{Abstrak}

Penelitian ini bertujuan untuk mengidentifikasi besaran sumber-sumber pendapatan asli daerah, langkah-langkah yang ditempuh dalam peningkatan pendapatan asli daerah (PAD), mengeksplorasi hambatan-hambatan yang terjadi dalam optimalisasi sumber-sumber PAD, dan solusi strategis dalam optimalisasi PAD.Metode penelitiannya adalah kuantitatif dan kualitatif (mix method).Hasil penelitian menunjukkan bahwa besaran keempat sumber pendapatan asli daerah mengalami trend pendapatan yang fluktuatif selama tahun 2013-2017.Kontribusi keempat sumber pendapatan asli daerah terhadap pendapatan daerah dinilai masih rendah.Faktor-faktor penghambat optimalisasi pendapatan asli daerah Provinsi NTT terdiri dari faktor internal dan eksternal.Faktor internal meliputi budaya kelembagaan, administrasi (biaya operasional), teknologi informasi, kondisi geografis, kualitas dan kuantitas SDM.Sedangkan, faktor eksternal meliputi kepentingan politik tertentu, kondisi ekonomi masyarakat dan kesadaran masyarakat. Strategi-strategi yang telah diimplementasi dalam optimalisasi pendapatan asli daerah Provinsi NTT antara lain; strategi intensifikasi, ekstensifikasi dan peningkatan mutu pelayanan. Melalui hasil AHP, alternatif strategi yang dipilih adalah mengoptimalkan strategi inovasi.

Keywords : Optimalisasi; Nusa Tenggara Timur; Pemerintah Provinsi Nusa Tenggara Timur, Pendapatan Asli Daerah; Keuangan. 


\section{Pendahuluan}

UU Nomor 23 Tahun 2014 tentang Pemerintahan Daerah memberi kewenangan yang besar kepada pemerintah daerah untuk mengatur dan mengurus rumah tangganya sendiri.Makna dari desentraliasi tidak hanya diartikan sebagai penyerahan kewenangan secara politik dan administratif, tetapi juga penyerahan kewenangan dari sektor fiskal.Ini berarti desentralisasi fiskal memberikan kesempatan kepada pemerintah daerah untuk menggali sumber pendapatan asli daerahnya sendiri sesuai dengan kebutuhan dan potensi daerah, mengelola keuangan sendiri dan mempergunakannya sesuai dengan perencanaan sebelumnya (Soleh, 2010 dalam Runiawati, 2015).Tuntutan dari desentralisasi fiskal adalah pemerintah daerah meningkatkan kreativitas dalam menghimpun pendanaan sehinga dapat membiayai atau self financing pengeluaran daerah sesuai dengan kebutuhannya.Wujud dari self financing adalah dengan memelihara dan mengelola sumber-sumber pendapatan agar kontribusi pendapatan asli daerah menunjukkan tren yang terus meningkat terhadap pendapatan daerah (Runiawati, 2015).

Salah satu ciri utama yang menunjukkan suatu daerah otonom mampu berotonomi adalah kemandirian keuangan daerah.Artinya, daerah otonom memiliki kewenangan dan kemampuan untuk menggali sumber-sumber keuangan sendiri, mengelola dan menggunakan secara memadai untuk membiayai pemerintahan daerahnya.Kondisi yang terjadi di Pemerintah Provinsi Nusa Tenggara Timur menunjukkan adanya peningkatan pendapatan asli daerah (PAD) yang positif dari tahun ke tahun.Data menunjukkan bahwa pendapatan asli daerah provinsi NTT pada Tahun 2017 sebesar Rp 1, 090 triliun. Peningkatan pendapatan asli daerah (PAD) Provinsi NTT tersebut, menurut UU Nomor 33 Tahun 2004 bersumber dari penerimaan pajak, retribusi, pengelolaan kekayaan lainnya yang dipisahkan dan lain-lain pendapatan yang sah. Menurut UU Nomor 28 Tahun 2009, jenis pajak yang dipungut oleh provinsi, yakni; pajak kendaraan bermotor, bea balik nama kendaraan bermotor dan pajak bahan bakar kendaraan bermotor, pajak air permukaan dan pajak rokok. Menurut ketentuan pasal 1 UU Nomor 28 Tahun 2009, retribusi daerah atau pungutan daerah adalah pembayaran atas jasa atau pemberian izin tertentu yang khusus disediakan dan/atau diberikan oleh pemerintah daerah untuk kepentingan orang pribadi atau badan. Berdasarkan UU Nomor 28 Tahun 2009 tentang perubahan Undang-Undang Nomor 34 Tahun 2000 dan UU Nomor 18 Tahun 1997 tentang pajak daerah dan retribusi daerah, retribusi daerah dibagi menjadi tiga golongan, yaitu; retribusi jasa umum, jasa usaha dan perizinan tertentu (Siahaan, 2013). Undang-undang Nomor 33 Tahun 2004 mengklasifikasikan jenis hasil pengelolaan kekayaan daerah yang dipisahkan, dirinci menurut objek pendapatan yang mencakup bagian laba atas penyertaan modal pada perusahaan milik daerah/BUMD, bagian laba atas penyertaan modal pada perusahaan Negara/BUMN dan bagian laba atas penyertaan modal pada perusahaan milik swasta atau kelompok masyarakat (Halim, 2004:68 dalam Ginzel, 2017). Sedangkan, dalam UU Nomor 33 Tahun 2004, lain-lain pendapatan asli daerah (PAD) meliputi; hasil penjualan kekayaan daerah yang tidak dipisahkan, jasa giro, pendapatan bunga, keuntungan selisih nilai tukar rupiah terhadap mata uang asing; dan komisi, potongan, ataupun bentuk lain sebagai akibat dari penjualan dan/atau pengadaan barang dan/atau jasa oleh daerah.

Berbagai upaya yang dilakukan Pemerintah Provinsi NTT selama ini dalam meningkatkan pendapatan asli daerah (PAD), seperti perbaikan sistem informasi keuangan daerah, penataan SDM, pendekatan pelayanan pajak dan retribusi, serta pengelolaan barang milik daerah juga terus dilakukan. Pelaksanaan berbagai upaya tersebut dapat meningkatkan pendapatan asli daerah (PAD).Peningkatan pendapatan asli daerah (PAD) Provinsi NTT terus didorong peningkatannya selama tahun 2018-2023. Target peningkatan pendapatan asli daerah (PAD) Pemerintah Provinsi NTT selama lima tahun ditetapkan sebesar Rp 3, 219 triliun. Oleh karena itu,untuk mencapai peningkatan pendapatan asli daerah (PAD) tersebut, Pemerintah Provinsi NTT dituntut kreatif dalam mengoptimalkan sumbersumber-sumber pendapatan asli daerah (PAD) yang ada.

\section{Kerangka Teori}

Kaitan dengan itu, terdapat beberapa strategi dalam meningkatkan pendapatan asli daerah (PAD), antara lain: strategi inovasi, strategi peningkatan kualitas yang menekankan pada penjabaran deskripsi kerja, partisipasi dalam pengambilan keputusan, penilaian pekerjaan, keseragaman perlakuan serta pelatihan dan pengembangan kualitas (Simamora, 1995) dalam Jufrizal dan Sujianto, 2015). Intensification strategy.Strategi intensifikasi diartikan sebagai suatu usaha yang dilakukan oleh pemerintah daerah untuk meningkatkan penerimaan PAD yang ditempuh melalui peningkatan kepatuhan subjek yang telah ada. Upaya intensifikasi akan mencakup aspek kelembagaan, aspek ketatalaksanaan, dan aspek personalianya (Kustiawan, 2010 dalam Rahmi 2016). Extensification strategy; Ekstensifikasi diartikan sebagai suatu kegiatan ekspansi untuk menambah objek-objek maupun subjek-subjek penerimaan daerah serta dikelola secara baik (Bawazier, 1998 dalam Rahmi, 2016; Kamaluddin 1995, dalam Rahmi, 2016). 
Meskipun demikian, dalam optimalisasi PAD oleh Roy Bahl, et.al (1990:396) dalam Sobandi (2016) mendeskripsikan beberapa kendala, di antaranya; pertama, dukungan regulasi dan kepentingan politik pihak tertentu (legal and political constrainst). Kedua, kendala dalam aspek administratif (administrative structure constrainst).Kendala ini meliputi kondisi birokrasi pemerintahan yang lemah dan kaku, kemampuan SDM, sistem dan prosedur yang lamban.Ketiga, kondisi perekonomian daerah (economic constraints).Kebijakan pembenahan sumber keuangan daerah kurang didukung oleh kemampuan perekonomian daerah yang belum baik.Keempat, kendala teknologi, budaya dan kelembagaan (technological constraint).Dalam hal ini, kemampuan teknologi termasuk metode yang diperlukan untuk mendukung reformasi penerimaan.Kelima, cultural and institutionalconstraint. Kondisi budaya masyarakat yang kurang respons terhadap kebijakan pemerintah, serta kelembagaan birokrasi yang kurang akomodatif.

\section{Metode}

Metode kelitbangan yang digunakan adalah kuantitatif dan kualitatif (mix method).Teknik penarikan sampel menggunakan purposive sampling dengan pertimbangan tujuan penelitian. Oleh karena itu, sampel (responden dan informan) yang ditetapkan adalah pimpinan perangkat daerah yang menghasilkan PAD di antaranya; Dinas Perhubungan, Dinas Pekerjaan Umum, Dinas Kehutanan, Dinas Lingkungan Hidup, Dinas Kesehatan, Dinas Pemuda dan Olahraga, Dinas Kelautan dan Perikanan, Dinas Peternakan dengan 5 Kepala UPT Dispenda, yakni UPT Dispenda Manggarai Barat, UPT Dispenda Sumba Timur, UPT Samsat Belu, UPT Samsat Kota Kupang, UPT Dispenda Sikka.Ada tiga teknik analisis data dalam kajian ini, antara lain; perhitungan statistik distribusi frekuensi, deskripsi dan eksplanasi kualitatif, AHP (analisis hirarki proses). Teknik pengumpulan data dilakukan dengan wawancara tertulis, pengisian kuesioner, dan studi dokumen.

\section{Hasil dan Pembahasan}

4.1. Sumber-Sumber Pendapatan Asli Daerah Provinsi Nusa Tenggara Timur

Pada tabel 1.1 Realisasi Pendapatan Asli Daerah (PAD) Provinsi NTT periode 2013 -2017, menunjukkan bahwa besarnya persentase PAD yang terealisasi berturut-turut adalah 109.7576\%, $103.8780 \%$, 101.1195\%, 122.79\%, 99.1801\% dan $103.0972 \%$. Data di atas menunjukkan bahwa persentase realisasi tertinggi dan paling memuaskan adalah di tahun 2013 yaitu sebesar 109,7576\%, sementara persentase realisasi yang paling rendah adalah tahun 2016 yaitu 99,1801\%.

\section{Realisasi Pendapatan Asli Daerah (\%)}

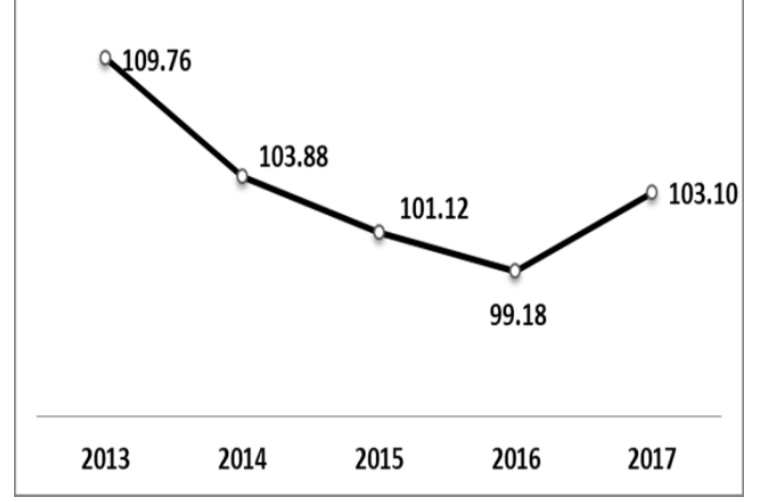

Gambar 1. Persentasi Realisasi Pendapatan Asli Daerah

Provinsi Nusa Tenggara Timur Periode 2013 - 2017

Berdasarkan data yang diperoleh dari Dispenda Provinsi NTT Periode 2013-2017 bahwa penerimaan PAD berdasarkan komponen-komponennya menunjukkan adanya peningkatan dan penurunan.Hal ini terjadi karena adanya fluktuasi kondisi ekonomi masyarakat Provinsi NTT.Realisasi Pajak Daerah Provinsi NTT periode 2013-2017 menunjukkan bahwa jumlah realisasi pajak daerah dari tahun 20132015 mengalami penurunan, meskipun pada awal tahun berikutnya mengalami peningkatan. Persentase realisasi pajak daerah tertinggi adalah pada tahun 2013 sebesar $112.7281 \%$, sedangkan terendah adalah pada tahun 2015 sebesar 100,5983\%.

Realisasi Retribusi Daerah Provinsi NTT periode 2013 - 2017, menunjukkan persentase realisasi berturut-turut adalah 73,9899\%, 69,8496\%, $85,9173 \%, 88,3076 \%$ dan 96,2552\%. Adanya penurunan persentase realisasi terjadi pada tahun 2013 - 2014, yaitu sebesar 4,1403\%, kemudian untuk tahun 2015- 2017 persentase ini kembali meningkat, meskipun realisasi tahun 2017 mengalami penurunan yaitu Rp. 24,266,495,631,00,dari Rp. 40,418,137,792, 00,- .

Realisasi Hasil Pengelolaan Kekayaan Daerah Yang Dipisahkan Provinsi NTT periode 2013- 2017 menunjukkan bahwa persentase realisasi penerimaan dari sektor hasil pengelolaan kekayaan daerah yang dipisahkan dari tahun ke tahun mengalami penurunan. Adapun persentasi realisasi berturut-turut adalah $\quad 100,0007 \%, \quad 100,0000 \%, \quad 99,9744 \%$, $99,3560 \%$ dan $99.4265 \%$. Tahun 2013 merupakan persentase yang tertinggi jika dibandingkan dengan tahun lainnya yaitu sebesar $100,0007 \%$, sedangkan persentase terendah adalah di tahun 2016 yaitu sebesar $99,3560 \%$.

Realisasi Pendapatan Lain- Lain Pendapatan Asli Daerah Provinsi NTT periode2013 - 2017, menunjukkan bahwa persentase realisasi penerimaan dari sektor lain-lain PAD berturut-turut adalah $109,50 \%, 126,57 \%, 110,81 \%, 87,90 \%$ dan $100,45 \%$. 


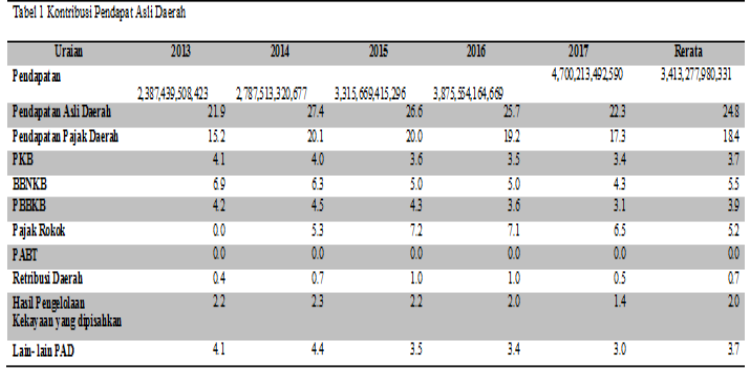

Persentase tertinggi adalah di tahun 2014 sebesar 126,57\%. Sedangkan terendah di tahun 2016 sebesar $87,90 \%$.

4.2. Kontribusi Sumber-Sumber Pendapatan Asli

Daerah Provinsi NTT

Pada tahun 2013 penerimaan dari sektor pajak daerah memberikan kontribusi terbesar yaitu 69,52\% terhadap pendapatan daerah secara keseluruhan. Tahun 2013 ini merupakan persentasi kontribusi yang terkecil yang diberikan pajak daerah kepada pendapatan daerah.Persentasi kontribusi penerimaan pajak daerah dari tahun ke tahun menunjukkan peningkatan diikuti dengan peningkatan nominal pendapatan pajak daerah. Pada tahun 2013 penerimaan sebesar Rp. 363.720.612.876,00,- diikuti tahun 2014 sebesar Rp. 559.803.345.782,00,kemudian pada tahun berikutnya sebesar Rp. 662.667.383.501,00,- seterusnya pada tahun 2016 sebesar Rp. 745.481.335.512,06,- dan meningkat menjadi Rp. 81.122.727.71,00,- pada tahun 2017.

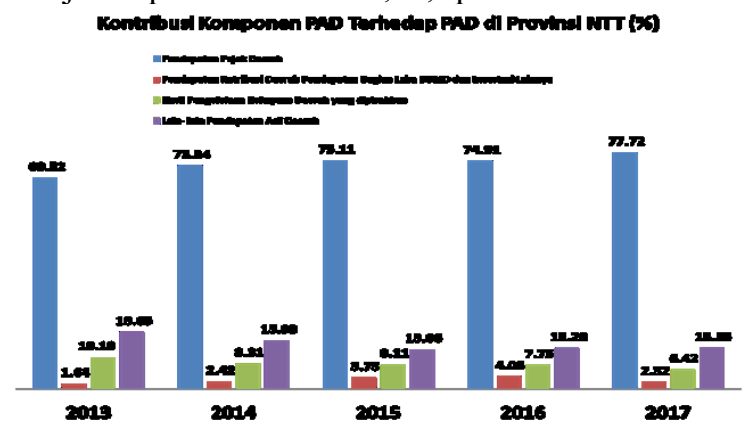

Gambar 2. Kontribusi Persentasi Komponen PAD terhadap Pendapatan Asli daerah Provinsi Nusa Tenggara Timur Periode 2013 - 2017

Komponen terbesar kedua yang berkontribusi terhadap PAD adalah Lain- Lain Pendapatan Asli Daerah yaitu sebesar $18,65 \%$ pada tahun 2013 , $15,93 \%$ di tahun $2014,13,06$ di tahun $2015,13,55 \%$ di tahun 2016 dan $13,55 \%$ di tahun 2017. Berdasarkan gambar 2 di atas, dapat dilihat bahwa persentasi kontribusi lain-lain pendapatan asli daerah mengalami penurunan meskipun secara nominal ada peningkatan di tahun 2014, 2016 dan 2017 (Tabel 1.1).

Kontribusi terbesar periode 2013 - 2017 berikutnya diikuti oleh pendapatan Hasil Pengelolaan Kekayaan Daerah yang dipisahkan dengan nilai kontribusi berturut- turut setiap tahun sebesar $10,19 \%, 8,31 \%$, $8,11 \%, \quad 7,75 \%$ dan $6,42 \%$. Meskipun secara persentasi mengalami penurunan, namun secara nominal pendapatan hasil pengelolaan kekayaan daerah meningkat dari tahun 2013 hingga tahun 2016 dan menurun di tahun 2017 yaitu Rp. 67.209.561.753,00,--.

Pendapatan retribusi daerah memberikan kontribusi persentasi terkecil dibandingkan komponen lainnya. Persentasi kontribusi retribusi periode tahun 2013 2017 berturut- turut sebesar 1,64\%, 2,42\%, 3,73\%, 4,06\% dan 2,32\%. Meskipun demikian, nominal retribusi daerah mengalami kenaikan dari tahun 2013 hingga 2016 sebesar Rp. 8.589.942.871,00,- , Rp. 18.447.549.341,00- , Rp. 32.888.198.526,00,- dan Rp. 40.418.137.792,00,- dan menurun pada tahun 2017 yaitu Rp. 24.266.495.631,00.--

4.3. Analisis Rasio Kontribusi Komponen Pendapatan Asli Daerah

Tabel 2. Hasil Analisis Rasio Kontribusi Komponen Pendapatan Asli Daerah

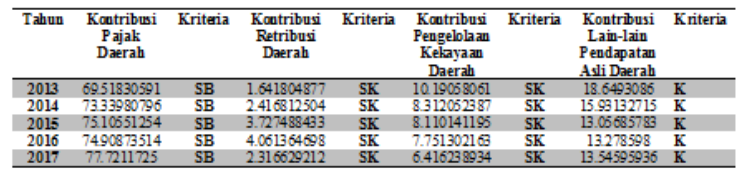

Sumber: Diolah Tim Peneliti, 2018

4.4. Proyeksi Pendapatan Daerah Provinsi NTT Tahun 2019 - 2023

Proyeksi pendapatan daerah dihitung berdasarkan angka elastisitas Total Pendapatan Daerah (TPD) terhadap Produk Domestik Regional Bruto (PDRB) atas dasar harga berlaku. Elastisitas TPD terhadap PDRB adalah sebagai berikut :

Elastisitas TPD terhadap PDRB $=\frac{\% \text { Perubahan TPD }}{\% \text { Perubahan PDRB }}$

Tabel 3. Total Penerimaan Daerah (TPD) danProduk Domestik Regional Bruto (PDRB) Provinsi NTT Tahun 2013 - 2017.

\begin{tabular}{|c|c|c|c|c|}
\hline Tabuu & TPD(Rp. Juta) & Perubahan $(0,6)$ & PDRB (Rp. Juta) & Perubahan ( 99 \\
\hline 2013 & $2,387,439,508,423$ & - & $61,325,300,000,000$ & - \\
\hline 2014 & $2,787,513,320,677$ & 16.76 & $68,500,400,000,000$ & 11.70 \\
\hline 2015 & $3,315,669,415,296$ & 18.95 & $76,120,800,000,000$ & 11.12 \\
\hline 2016 & $3,875,554,164,669$ & 16.89 & $83,947,800,000,000$ & 10.28 \\
\hline 2017 & $4,700,213,492,590$ & 21.28 & $91,159,700,000,000$ & 859 \\
\hline Rerata & $3,413,277,980,331$ & 18.47 & $72,473,575,000,000$ & 10.42 \\
\hline
\end{tabular}

Sumber : APBD dan PDRB Provinsi NTT 2013-2017

Berdasarkan data di atas maka elastisitas TPD terhadap PDRB adalah sebagai berikut :

$$
\text { Elastisitas TPD terhadap PDRB }=\frac{18,47}{10,42}=1,77
$$

Dari angka tersebut dapat diartikan bahwa jika terjadi peningkatan PDRB sebesar 1 satuan maka TPD akan mengalami peningkatan sebesar 1,77 satuan. Jika diasumsi pertumbuhan PDRB mengalami peningkatan setiap tahun sebesar 4,92\%, maka proyeksi pertumbuhan PDRB per tahun terlihat pada tabel 10. Angka 4,92\% diperoleh dari angka terendah peningkatan pertumbuhan PDRB selama periode 2013-2017. Dengan diketahui proyeksi pertumbuhan PDRB per tahun maka proyeksi 
FLOBAMORA, Juni 2019, Vol 2, No. 1, pp. 26-34 http://www.flobamora.e-journal.id/flobamora/ 30 p-ISSN 0216-2741; e-ISSN:

pertumbuhan TPD per tahun juga dapat dihitung. Dengan demikian proyeksi TPD juga dapat dihitung.

Tabel 4. Proyeksi Pertumbuhan PDRB dan TPD Provinsi NTT Tahun $2019-2023$

\begin{tabular}{|c|c|c|c|c|}
\hline Tahn & $\begin{array}{c}\text { Elastisitas } \\
\text { TPD } \\
\text { Erhadap } \\
\text { PDRB }\end{array}$ & $\begin{array}{c}\text { Proyeisi } \\
\text { Pertumbuhan } \\
\text { PDRB }(\%)\end{array}$ & $\begin{array}{c}\text { Proyelsi } \\
\text { Perturnbuhan } \\
\text { TPD (\%) }\end{array}$ & $\begin{array}{c}\text { Proyeksi TPD } \\
\text { (Rp.Juta) }\end{array}$ \\
\hline 2019 & 1.77 & 5.16 & 9.1332 & $\begin{array}{c}5,235,366,921, \\
657.840\end{array}$ \\
\hline 2020 & 1.77 & 5.2092 & 9220284 & $\underset{276.750}{5,78,082,620}$ \\
\hline 2001 & 1.77 & 5.2584 & 9307368 & $\begin{array}{c}6,250,285,612 \\
289.950\end{array}$ \\
\hline 2002 & 1.77 & 5.3076 & 9394452 & $\begin{array}{c}6,837,465,693, \\
999.440\end{array}$ \\
\hline 2023 & 1.77 & 5.3568 & 9.481536 & $\begin{array}{c}7,485,762,465 \\
263.640 \\
\end{array}$ \\
\hline
\end{tabular}

Sumber: Diolah Peneliti, 2018

Selanjutnya untuk menghitung proyeksi besarnya pendapatan daerah menurut jenis pendapatan dapat dilakukan dengan mengalikan proporsi rata-rata untuk masing-masing jenis penerimaan dengan TPD, seperti terlihat pada tabel 5 di bawah ini.

Tabel 5. Proyeksi Pendapatan Asli Daerah

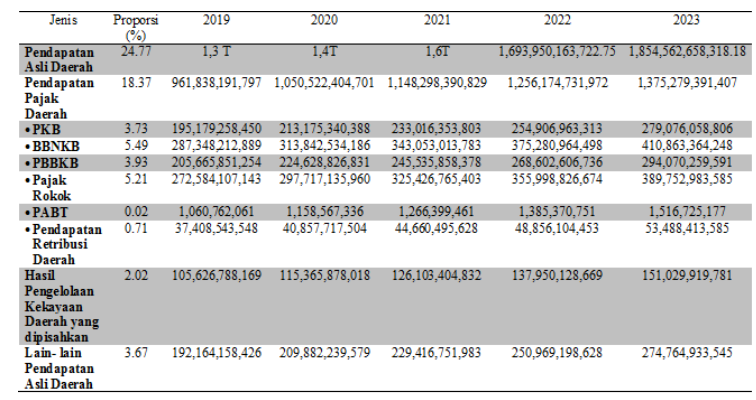

Sumber: Diolah Peneliti, 2018

Dari data hasil proyeksi pendapatan daerah pada tabel di atas, menunjukkan bahwa dari tahun 2019 sampai dengan tahun 2023 terjadi peningkatan pertumbuhan pendapatan daerah rata-rata sebesar 7,74\%.Proyeksi ini dibuat dengan asumsi bahwa pertumbuhan ekonomi daerah Provinsi NTT mulai tahun 2019 sampai dengan tahun 2023 mengalami pertumbuhan yang konstan dengan tingkat pertumbuhan ekonomi pada tahun 2023 diperkirakan sekitar 5,36\%.Artinya bahwa pertumbuhan ekonomi Provinsi NTT akan mengalami pertumbuhan yang optimis meningkat setiap tahunnya seiring dengan membaiknya kondisi perekonomian secara nasional.

Dari data hasil proyeksi pendapatan daerah pada tabel 5 di atas, menunjukkan bahwa dari tahun 2019 sampai dengan tahun 2023 terjadi peningkatan pertumbuhan pendapatan daerah rata-rata sebesar 7,74\%.Proyeksi ini dibuat dengan asumsi bahwa pertumbuhan ekonomi daerah Provinsi NTT mulai tahun 2019 sampai dengan tahun 2023 mengalami pertumbuhan yang konstan dengan tingkat pertumbuhan ekonomi pada tahun 2023 diperkirakan sekitar 5,36\%.Artinya bahwa pertumbuhan ekonomi
Provinsi NTT akan mengalami pertumbuhan yang optimis meningkat setiap tahunnya seiring dengan membaiknya kondisi perekonomian secara nasional.
4.5. Identifikasi
Faktor-Faktor
Penghambat

Optimalisasi PAD Provinsi NTT

Hasil pengumpulan data mengungkapkan beberapa temuan terkait faktor-faktor penghambat optimalisasi pendapatan asli daerah (PAD) provinsi NTT;

Tabel 6. Identifikasi Faktor-Faktor Penghambat Optimalisasi PAD

\begin{tabular}{|c|c|c|}
\hline Komponen PAD & \multicolumn{2}{|c|}{ Faktor-Faktor Pengham bat } \\
\hline \multirow{6}{*}{ Pajak } & Internal & Eksternal \\
\hline & $\begin{array}{l}\text { Kendala administrasi (data } \\
\text { wajib dan objek pajak: belum } \\
\text { valid) }\end{array}$ & $\begin{array}{l}\text { Kesaderan masyarakat } \\
\text { (wajib pajak) }\end{array}$ \\
\hline & $\begin{array}{l}\text { Telknologi informasi } \\
\text { (gangguan jaringan) }\end{array}$ & \\
\hline & $\begin{array}{l}\text { Biays operasional yang } \\
\text { masih terbatas }\end{array}$ & \\
\hline & $\begin{array}{l}\text { Kualitas dan luantitas SDM } \\
\text { yang mash̆ terbatas }\end{array}$ & \\
\hline & Kondisi geografis & \\
\hline \multirow[t]{5}{*}{ Retribusi } & $\begin{array}{l}\text { Regulasi yang belum } \\
\text { kontekstal direvisi }\end{array}$ & $\begin{array}{l}\text { Kesadaran } \\
\text { retribusi }\end{array}$ \\
\hline & $\begin{array}{l}\text { Kendala administrasi (data } \\
\text { wajib dan objek retribusi } \\
\text { belum valid }\end{array}$ & Situasi Politik \\
\hline & $\begin{array}{l}\text { Teknologi informasi (belum } \\
\text { digunakan manajemen kas } \\
\text { elektronik) }\end{array}$ & $\begin{array}{l}\text { Kondisi perekonomian } \\
\text { masyarakat daerah }\end{array}$ \\
\hline & $\begin{array}{l}\text { Biaya opera sional yang } \\
\text { masih terbatas di lapangan }\end{array}$ & \\
\hline & $\begin{array}{l}\text { Kualitas dan luantitas SDM } \\
\text { yang mash terbatas }\end{array}$ & \\
\hline \multirow[t]{4}{*}{$\begin{array}{l}\text { Hasil pengelolaan } \\
\text { kekayaan lain yang } \\
\text { dipisahkan }\end{array}$} & $\begin{array}{l}\text { Kendala administrasi (kredit } \\
\text { macet karena pendataan } \\
\text { nasabah yang kurang akurat) }\end{array}$ & $\begin{array}{l}\text { Kepentingan } \\
\text { tertentv }\end{array}$ \\
\hline & Telknologi $\quad$ informasi & Kondisi perekonomian \\
\hline & & daerah/masyarakat \\
\hline & $\begin{array}{l}\text { Kelemba gaan (pergantian } \\
\text { pimpinan pene tapan } \\
\text { pimpinan) }\end{array}$ & \\
\hline $\begin{array}{l}\text { Lain-lain PAD yan } \\
\text { sah }\end{array}$ & $\begin{array}{l}\text { Kondisi BMD (asset) } \\
\text { Kebijakan pemerintah daerah } \\
\text { dalam pengelolaan BMD } \\
\text { (sewa dan BGS) }\end{array}$ & $\begin{array}{l}\text { Kondisi perekonomian } \\
\text { daerah }\end{array}$ \\
\hline
\end{tabular}

Sumber: Diolah Peneliti, 2018

Optimalisasi PAD seringkali berhadapan dengan berbagai faktor internal yang menghambat mekanisme kerja aparatur atau birokrat pemerintahan. Birokrasi dalam artian administrasi dan sebagai suatu sistem, dalam studi administrasi publik telah mengungkapkan beberapa patologi birokrasi yang menghambat proses kerja, seperti; kelambanan proses administrasi, ketidakakuratan administrasi dan soal efisiensi. Patologi birokrasi ini ditemui juga dalam perangkat daerah atau unit teknis yang berhubungan dengan pendapatan (pelayanan publik).Dalam kajian ini, hasil pengumpulan data memotret problem-problem yang terjadi dalam pemungutan pajak dan retribusi, seperti; data objek pajak dan retribusi yang belum valid dari tahun ke tahun, data wajib pajak, sehingga menghambat penerapan teknologi informasi dalam penataan manajamen kas secara elektronik.Oleh karena itu, penerapan teknologi informasi yang terintegrasi dalam pendataan wajib pajak mutlak dilaksanakan.

Berbagai kendala administrasi di atas mencerminkan atau merepresentasikan budaya 
kelembagaan (birokrasi) secara umum yang masih ditunjukkan saat ini dalam pemungutan pajak, retribusi dan lain-lain pendapatan yang sah.Budaya kelembagaan yang masih kental birokratis tampak juga dalam menghasilkan produk hukum dalam urusan-urusan operasional.Regulasi yang belum berubah, belum update dan belum konteksual minim dihasilkan karena soal administrasi birokrasi itu sendiri yang hirarkis, prosedural, sehingga bermakna birokrasi lamban (Bahl, et. al., 1990, dalam Sobandi, 2016).

Selain itu, adanya potensi penerimaan pajak yang relatif meningkat memerlukan biaya operasional yang relatif besar masih terjadi di lapangan.Biaya operasional diperlukan juga untuk mendapatkan penerimaan yang relatif lebih besar terhadap wajib pajak dan retribusi yang bermasalah.Langkah pemerintah ini telah disinggung oleh Peacock dan Wiseman dalam intisari teorinya yang menandaskan bahwa pemerintah senantiasa berusaha memperbesar pengeluaran, sedangkan masyarakat tidak suka membayar pajak dan kewajiban lainnya yang semakin besar untuk membiaya pengeluaran pemerintah yang semakin besar tersebut (Santoso, dan Rahayu, 2005).

Pada komponen hasil kekayaan lain yang dipisahkan, optimalisasi PAD berhadapan dengan persoalan internal BUMD atau perusahaan swasta milik daerah yang meliputi kelembagaan, dan sumber daya manusia (personalia). Faktor-faktor internal tersebut menunjukkan kurangnya profesionalisme kerja, sehingga berdampak pada laba yang dihasilkan.

Sedangkan, pada komponen lain-lain pendapatan asli daerah yang sah, salah satu item pendapatan yang diungkapkan adalah pengelolaan asset-asset atau barang milik daerah (BMD). Data menunjukkan bahwa produk hukum yang ditetapkan terkait tariff sewa (misalnya rumah dinas dan asset gedung lainnya) belum direvisi (masih menggunakan Perda No 09 Tahun 2011), sehingga harga tariff sewa dinilai rendah untuk saat ini. Persoalan tersebut disebabkan oleh kondisi beberapa asset atau barang milik daerah (BMD) (misalnya, rumah dinas) Pemerintah Provinsi NTT yang dinilai kurang baik. Padahal, revisi sebuah regulasi mempertimbangkan jangka waktu produk hukum tersebut dihasilkan dan dinamikan kondisi perekonomian daerah. Kebijakan pemerintah dalam pengelolaan barang milik daerah yang masih terbatas disebabkan karena kondisi atau status barang milik daerah yang potensial masih dalam proses penataan administrasi dan yuridis.

Selain faktor internal, optimalisasi PAD provinsi NTT mengalami juga problem-problem eksternal.Pandangan (Bahl, et. al, 1990 dalam Sobandi, 2016) yang mengurai kendala-kendala eksternal, seperti; kepentingan politik tertentu dan kondisi perekonomian daerah ditemukan juga dalam optimalisasi PAD provinsi NTT.Kepentingan politik tertentu terlihat dalam pembahasan regulasi yang menetapkan besaran tarif dan penetapan besaran anggaran dalam rangka mendukung pelaksanaan pemungutan.Selain itu, faktor kondisi perekonomian daerah yang diungkapkan dalam pengumpulan data menyoal juga kondisi daya beli masyarakat yang fluktuatif dari waktu ke waktu, sehingga trend pendapatan pada beberapa item masih kurang signifikan peningkatannya.Di sini, peran pemerintah daerah dalam meningkatkan ekonomi kreatif melalui kebijakan-kebijakan yang dihasilkan sangat diperlukan.

Pada komponen hasil kekayaan daerah yang dipisahkan, faktor kepentingan politik tertentu terjadi juga dalam pemilihan pimpinan BUMD atau perusahaan swasta sehingga mereduksi arti profesionalisme. Hal ini tentunya turut memengaruhi proses kerja lembaga yang berimplikasi terhadap besaran laba yang diperoleh. Sedangkan, pada komponen lain-lain pendapatan asli daerah yang sah, faktor kondisi ekonomi daerah mempengaruhi optimalisasi pendapatan asli daerah.

4.6. Mengungkap Sebab-Musabab Faktor-Faktor

Penghambat Optimalisasi Pendapatan Asli

Daerah (PAD) Provinsi NTT

Beberapa faktor yang menghambat optimalisasi pendapatan asli daerah (PAD) di atas dilatarbelakangi oleh beberapa sebab musabab. Ada beberapa sebab yang diungkapkan dalam hasil pengumpulan data di antaranya;

Tabel 7. Akar Permasalahan Penghambat Pendapat Asli Daerah (PAD)

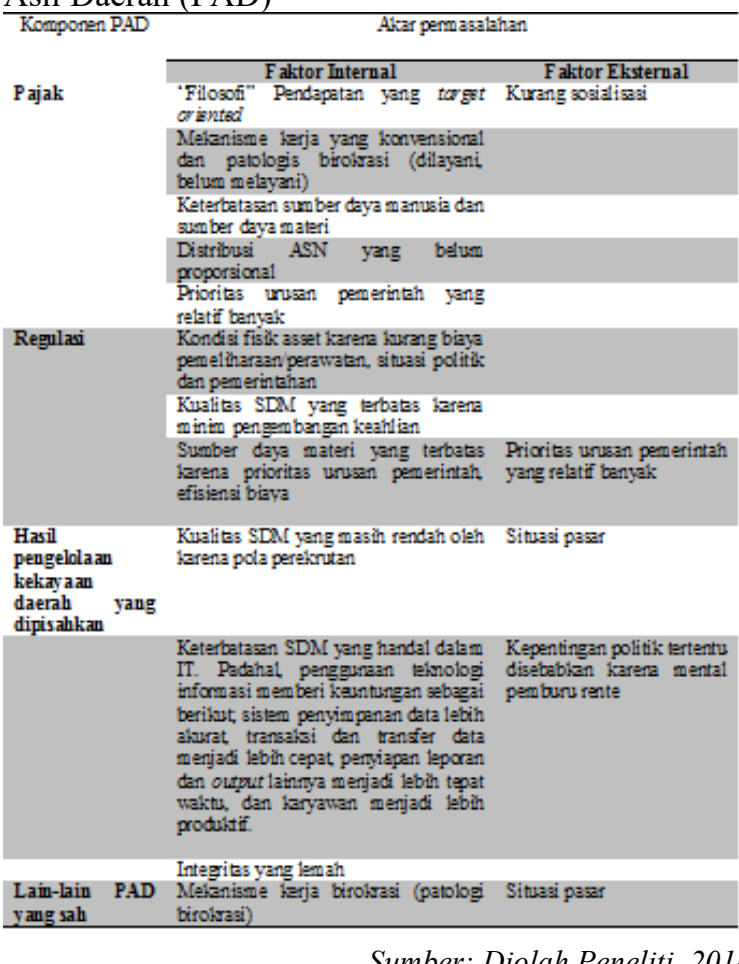

Sumber: Diolah Peneliti, 2018

4.7. Alternatif Strategi Optimalisasi Pendapatan Asli Daerah (PAD) Provinsi NTT 
Hasil pengumpulan data mengungkapkan beberapa temuan terkait implementasi strategi optimalisasi pendapatan asli daerah (PAD) provinsi NTT di antaranya;

1) Strategi intensifikasi

Strategi intensifikasi yang telah dilakukan dalam optimalisasi PAD pada komponen PAD, antara lain;

a) Pajak

Dari sektor pajak, hasil pengumpulan data mengungkapkan beberapa strategi intensifikasi yang telah dilaksanakan, di antaranya;

Pada aspek kelembagaan.Strategi yang sudah dilakukan meliputi pembenahan kelembagaan dan perangkatnya sesuai kebutuhan yang terus berkembang.Langkah aksi yang telah dilakukan seperti; pembentukkan UPT Pendapatan Daerah di seluruh provinsi NTT. Selain itu, dilakukan restrukturisasi berdasarkan aturan yang berlaku

Pada aspek ketatalaksanaan.Langkah-langkah strategis yang terus dilakukan adalah peningkatan dan pendataan wajib pajak, peningkatan pemungutan pajak dalam jumlah yang benar dan tepat, perbaikan sistem pembukuan atau manajemen kas, peningkatan pengawasan dan pengendalian (yuridis dan teknis) (penguatan tarif denda), peningkatan kerjasama dengan stakeholder terkait (kepolisian), peningkatan sosialisasi kepada wajib pajak, peningkatan mutu pelayanan.

Pada aspek personalia.Hasil pengumpulan data menunjukkan bahwa strategi yang telah dilakukan adalah peningkatan mutu SDM pengelola perpajakan daerah melalui bimtek, workshop, pendidikan dan pelatihan (diklat) dan penambahan jumlah personil bagi UPT yang membutuhkan dan kekurangan personil.

b) Retribusi

Dari sektor retribusi, hasil pengumpulan data mengungkapkan beberapa strategi intensifikasi yang dilaksanakan oleh Pemerintah Provinsi NTT, di antaranya;

Pada aspek kelembagaan. Strategi yang telah dilaksanakan antara lain; pembenahan struktur kelembagaan dan sistem retribusi berdasarkan regulasi yang berlaku.

Pada aspek ketatalaksanaan.Strategi intensifikasi yang telah dilakukan meliputi; peningkatan pengawasan dan pengendalian (yuridis dan teknis), penyesuaian tariff retribusi pada beberapa item retribusi, perbaikan administrasi pungutan, sosialisasi dan penyesuaian sistem pelaksanaan pemungutan serta peningkatan mutu pelayanan.

Pada aspek personalia.Strategi yang telah dilakukan adalah peningkatan mutu SDM pengelola retribusi daerah dan penambahan jumlah personil bagi UPT yang membutuhkan atau kekurangan personil.
Strategi yang telah dilakukan dalam optimalisasi PAD pada komponen PAD, antara lain;

a) Pajak

Dari sektor pajak, hasil pengumpulan data mengungkapkan beberapa strategi intensifikasi yang dilaksanakan, di antaranya;

Pada aspek kelembagaan, meliputi pembenahan kelembagaan dan perangkatnya secara terus-menerus sesuai kebutuhan yang terus berkembang dan menerapkan secara optimal sistem dan prosedur perpajakan daerah yang berlaku menurut dasar hukum yang berlaku.

Pada aspek ketatalaksanaan.Langkah-langkah strategis yang terus dilakukan adalah peningkatan dan pendataan wajib pajak secara akurat, peningkatan pemungutan pajak dalam jumlah yang benar dan tepat, perbaikan sistem pembukuan atau manajemen kas, peningkatan pengawasan dan pengendalian (yuridis dan teknis) (penguatan tarif denda), peningkatan kerjasama dengan stakeholder terkait, dan peningkatan sosialisasi kepada wajib pajak serta peningkatan mutu pelayanan.

Pada aspek personalia.Hasil pengumpulan data menunjukkan bahwa strategi yang telah dilakukan adalah peningkatan mutu SDM pengelola perpajakan daerah dan penambahan jumlah personil bagi UPT yang membutuhkan atau kekurangan personil.

b) Retribusi

Dari sektor retribusi, hasil pengumpulan data mengungkapkan beberapa strategi intensifikasi yang dilaksanakan oleh Pemerintah Provinsi NTT, di antaranya;

Pada aspek kelembagaan. Strategi yang telah dilaksanakan antara lain; pembenahan struktur kelembagaan dan sistem retribusi berdasarkan regulasi yang berlaku.

Pada aspek ketatalaksanaan.Strategi intensifikasi yang telah dilakukan meliputi; peningkatan pengawasan dan pengendalian (yuridis dan teknis), penyesuaian tariff retribusi pada beberapa item retribusi, perbaikan administrasi pungutan, sosialisasi dan penyesuaian sistem pelaksanaan pemungutan serta peningkatan mutu pelayanan.

Pada aspek personalia.Strategi yang telah dilakukan adalah peningkatan mutu SDM pengelola retribusi daerah dan penambahan jumlah personil bagi UPT yang membutuhkan atau kekurangan personil.

c) Lain-lain pendapatan yang sah

Hasil penelitian mengungkapkan beberapa strategi yang telah dilakukan oleh pemerintah provinsi NTT dalam optimalisasi PAD dari komponen lain-lain pendapatan yang sah di antaranya pengelolaan asset daerah Provinsi NTT dalam bentuk pemanfaatan dan sewa.

2) Strategi ekstensifikasi

Hasil pengumpulan data mengungkapkan bahwa strategi ekstensifikasi yang telah dilakukan 
oleh Pemerintah Provinsi NTT dalam optimalisasi pendapatan asli daerah (PAD) provinsi NTT di antaranya;

a) Pajak

Hasil pengumpulan data menunjukkan bahwa strategi ekstensifikasi yang telah dilakukan Pemerintah Provinsi NTT dalam optimalisasi pajak daerah antara lain; identifikasi wajib pajak baru/potensial dan jumlah wajib pajak, perbaikan basis data objek pajak dan menghitung kapasitas penerimaan dari setiap jenis pungutan. Hal lain yang dilakukan adalah pembenahan proses pungutan dari waktu ke waktu, penetapan target pendapatan melalui perencanaan yang baik, meningkatkan kapasitas penerimaan sekaligus melaksanakan pengawasan melalui berkoordinasi dengan stakeholder terkait.

b) Retribusi

Hasil pengumpulan data menunjukkan bahwa strategi ekstensifikasi yang telah dilakukan oleh pemerintah provinsi NTT dalam optimalisasi PAD dari retribusi adalah perluasan basis sumber-sumber retribusi (wajib retribusi dan ruang lingkup retribusi baru).

c) Lain-lain pendapatan yang sah

Strategi yang dilakukan adalah pemanfaatan asset-asset daerah atau barang milik daerah yang mendatangkan pendapatan bagi daerah.

3) Strategi peningkatan mutu atau kualitas pelayanan

Peningkatan mutu pelayanan bagi semua komponen penerimaan yang berhubungan dengan publik, investor dan stakeholder terkait.

Alternatif strategi pada kajian ini membatasi pada sumber pajak dan retribusi daerah. Melalui analisis hirarki proses (AHP), ditentukan alternatif strategi yang tepat dalam optimalisasi PAD terhadap sumber pajak dan retribusi daerah.

Untuk mendapatkan hasil keputusan, masingmasing bobot untuk alternatif pilihan dikalikan dengan bobot dari kriteria dalam bentuk perkalian matrik sebagai berikut:

\begin{tabular}{lllll} 
Intensifikasi & 0.1160 & 0.3790 & 0.3010 & 0.3196 \\
\hline Ekstensifikasi & 0.2470 & 0.2900 & 0.2390 & 0.5584 \\
$\begin{array}{l}\text { Mutu } \\
\text { pelayanan }\end{array}$ & 0.0600 & 0.0740 & 0.2120 & 0.1220 \\
Inovasi & 0.5770 & 0.2570 & 0.2480 & $\mathrm{X}$ \\
\hline
\end{tabular}

Sehingga perhitungan untuk intensifikasi keseluruhan nilai masing-masing alternatif pilihan sebagai berikut:

Intemifikasi 03060

\begin{tabular}{ll}
\hline Ekstemifikasi & 02720 \\
Mutu Felayanan & 0.0940 \\
Inowasi & 03280 \\
\hline
\end{tabular}

Dengan demikian, pilihan yang paling kuat untuk pemilihan strategi adalah strategi inovasi..

\section{Kesimpulan}

Trend penerimaan pajak daerah mengalami penurunan dari tahun 2013 ke tahun 2015 dari sisi persentase realisasinya dan meningkat kembali dari tahun 2015 ke tahun 2017, dengan rata-rata presentasi yang dicapai sebesar 102,26\%. Retribusi daerah mengalami trend peningkatan yang relatif baik, dari target ke target maupun realisasi ke realisasi meskipun terjadi penurunan nominal target pada tahun 2017 dengan presentasinya rata-rata capaian 82,8939\%. Pendapatan Hasil Pengelolaan Kekayaan Daerah yang Dipisahkan. Trend penerimaan mengalami peningkatan, baik dari sisi nominal target ke target mapun dari sisi nominal realisasi ke realisasi meskipun terjadi penurunan nominal target pada tahun 2017 dengan presentasinya rata-rata capaian 99,4265\%. Namun, dari sisi persentase target ke realisasi belum memenuhi target yang ditetapkan. Lain-lain Pendapatan Asli Daerah yang Sah mengalami fluktuasi dengan rerata presentase sebesar 107,046\%.

Kontribusi PAD terhadap Pendapatan Daerah (APBD) memiliki rata-rata sebesar 24,7745 \%. Artinya, sumbangan yang diberikan sebesar $24,7745 \%$ dan selebihnya sebesar 75,2255\% disumbang oleh sumber-sumber lain selain yang berasal dari PAD. Jika ditinjau dari tingkat kemandirian daerah, maka hasil perhitungan di atas, menunjukkan tingkat kemandirian yang masih sangat minim.

Faktor-faktor penghambat optimalisasi pendapatan asli daerah Provinsi NTT terdiri dari faktor internal dan eksternal. Faktor internal meliputi budaya kelembagaan, administrasi (biaya operasional), teknologi informasi, kondisi geografis, kualitas dan kuantitas SDM. Sedangkan, faktor eksternal meliputi kepentingan politik tertentu, kondisi ekonomi masyarakat dan kesadaran masyarakat.

Beberapa faktor penghambat tersebut disebabkan oleh kualitas SDM yang masih rendah, mekanisme atau budaya kerja, filosofi kerja dan keterbatasan sumber daya materi.

Alternatif strategi yang dapat dilaksanakan adalah mengoptimalkan strategi inovasi.

Strategi intensifikasi dapat dilakukan dengan langkah-langkah sebagai berikut; memperbaiki aspek kelembagaan dan perangkatnya, aspek ketatalaksanaan baik administrasi maupun operasional, pembenahan dan peningkatan aspek personalia, peningkatan dan pengawasan pengendalian yuridis, penatausahaan dan teknis, peningkatan kegiatan penyuluhan bagi masyarakat untuk kesadaran membayar pajak dan retribusi, 
penyesuaian tarif dan ketegasan dalam memberikan sanksi.

Strategi ekstensifikasi dapat dilakukan dengan langkah-langkah sebagai berikut; pendataan, pemetaan secara akurat, dan perluasan sumbersumber penerimaan yang baru dan kebijakan ikilim investasi yang kondusif, sehingga memudahkan investor dalam mengelola barang atau asset milik daerah Provinsi NTT.

Strategi peningkatan mutu pelayanan dapat dilakukan dengan pengembangan kualitas pengelola pendapatan dan memberi kemudahan bagi masyarakat dalam pelayanan.

Strategi inovasi dapat dilakukan dengan pengembangan keahlian kerja untuk menghasilkan teknologi informasi yang handal dan dapat diaplikasikan dalam optimalisasi pendapatan asli daerah provinsi NTT.

Perlu adanya langkah aksi melalui Pembentukkan Satuan Tugas atau Tim Peningkatan Pendapatan Asli Daerah (PAD) Provinsi NTT.

\section{Ucapan Terima Kasih (Acknowledgments)}

Ucapan terima kasih disampaikan kepada semua pihak yang telah membantu tim penulis dalam menyelesaikan tulisan ini.

\section{Referensi}

Basri, Syafril. 2015. Optimalisasi Penerimaan Daerah di dalam Peningkatan Kemampuan Keuangan Daerah Kota Pekanbaru. Jurnal Ilmiah.

Darmanto, Aresta. 2016. Optimalisasi Sumber Pendapatan Asli Daerah Dalam Pelaksanaan Otonomi Daerah Di Kabupaten Kutai Timur. Jurnal Ilmu Administrasi Bisnis, 4 (1): hal. 15-23.

Dedy, Ramdan Ruhedi. 2001. Upaya Intensifikasi dan Ekstensifikasi Pendapatan Asli Daerah.Dalam Manajemen Keuangan Daerah, Abdul Halim (ed). Yogyakarta: UPP AMP YKPN.

Ginzel, Alice Desly. 2017. Strategi Peningkatan Pendapatan Asli Daerah Pada Sektor Pajak Di Kabupaten Tambrauw Provinsi Papua Barat. Tesis.Institut Pertanian Bogor.

Jufrizal dan Sujianto.Strategi Peningkatan Pendapatan Asli Daerah. Jurnal Administrasi Pembangunan. Vol (1), 2: 101218.

Nuzulistan, Kendy Rama, et. all. 2016. Pengaruh Pajak Daerah, Retribusi Daerah, Hasil Pengelolaan Kekayaan Daerah yang Dipisahkan dan Lain-Lain Pendapatananan Daerah yang Sah Terhadap Pendapatan Asli Daerah Provinsi Jawa Tengah. Jurnal Ilmiah.
Rahmi, Ade. 2016. Pengaruh Intensifikasi dan Ekstensifikasi Terhadap Peningkatan Pendapatan Asli Daerah Guna Mewujudkan Kemandirian Keuangan Daerah.Tesis.Fakultas Ekonomi Universitas Padang.

Runiawati, Nunung. 2015. Pemanfaatan Barang Milik Daerah. Jurnal Ilmiah.

Santosa, Purbayu Budi dan Retno Puji Rahayu. 2005. Analisis Pendapatan Asli Daerah (PAD) dan Faktor-Faktor yang Mempengaruhinya dalam Upaya Pelaksanaan Otonomi Daerah di Kabupaten Kediri. Jurnal Dinamika Pembangunan, 2 (1): hal. 9-18.

Sobandi, Baban. 2016. Strategi Optimalisasi Pendapatan Asli Daerah (PAD): Kasus Kota Banjarmasin. Jurnal Ilmiah.

Yuliani, Yuyun. 2016. Analisis Pemanfaatan Sewa Barang Milik Daerah Pada Kabupaten Boyolali.Skripsi.Fakultas Ekonomi dan Bisnis. Universitas Muhammadiyah. Surakarta. 